\title{
TRACE METALS SPECIATION IN SEDIMENTS OF LAKE MANZALA, EGYPT
}

\author{
Mohamed A. Hamed ${ }^{1}$ and Mohamed A. Okbah ${ }^{2}$ \\ 1- National Institute of Oceanography \& Fisheries, Suez,Egypt. \\ 2- National Institute of Oceanography \& Fisheries Kayet Bay, \\ Alexandria, Egypt.
}

Key words: Speciation, trace metals, sediments, Lake Manzala

\section{ABSTRACT}

Sediment samples were collected during summer, 2004 from Lake
Manzala to determine the chemical association of trace metals (Fe, $\mathrm{Mn}, \mathrm{Cu}, \mathrm{Zn}, \mathrm{Pb}, \mathrm{Cd}, \mathrm{Co}, \mathrm{Ni}$ and $\mathrm{Cr}$ ) in the lake sediments. Five fractions were extracted using sequential extraction techniques, which represent the major sedimentary phases including the exchangeable, carbonate, Fe-Mn oxides, organic fraction and residual metal. The results of metals speciation indicated that, the high proportion of trace metals were presented in the residual fraction which represents $50 \%$ of the total metals for $\mathrm{Mn}, \mathrm{Cu}, \mathrm{Pb}$ and reached to $73 \%$ of the total for $\mathrm{Zn}$. The geochemical analysis of metal forms reflected the lithogenic origin of these metals in the study area.

The results also showed high percentage of $\mathrm{Fe}, \mathrm{Co}, \mathrm{Ni}$ and $\mathrm{Cr}$ in the organic fractions ( $40 \%$ of the total metal). High percentage of $\mathrm{Cd}$ was found in the carbonate fraction (32\%). However, few percentages were recorded in the exchangeable fraction of $\mathrm{Fe}, \mathrm{Cu}$ and $\mathrm{Zn}(<1 \%$ of total content), while increased from 2 to $6 \%$ of total $\mathrm{Mn}, \mathrm{Cr}, \mathrm{Co}, \mathrm{Ni}$ and reached to $6 \%$ for $\mathrm{Pb}$ and $12 \%$ for $\mathrm{Cd}$. It is evident from the results that the sediments of Lake Manzala are highly polluted with $\mathrm{Cd}, \mathrm{Cr}, \mathrm{Ni}$ and $\mathrm{Co}$, and the greater amount of these were found in the non-lithogeous origin (exchangeable, carbonate, oxides and organic materials).

Multivariate techniques of statistical analysis have been applied to a set of chemical forms of metals obtained by the analysis of Lake Manzala sediments. The correlation matrix and principal component analysis were performed to show the behavior of the nine metals in each fraction. 


\section{INTRODUCTION}

Lake Manzala is the largest of the Nile Delta lagoons which is located at the coastal area of the Mediterranean sea of Egypt. It receives drainage water from several drains which serve as sources of pollution. Sediments act as both carriers and potential sources of contaminants in an aquatic environment. Anthropogenic activities, industrial and urban wastes as well as agriculture wastewater play an important role in influencing the pollution of the lake water and sediments.

Because the heavy metals can be either adsorbed onto sediments or accumulated by benthic organisms to a toxic level, the bioavailability and subsequent toxicity of the metals are dependent upon various kinds and amounts of the metals bound to the sediment matrices ( $\mathrm{Yu}$ et al., 2001). Most studies are concerning with the total concentration of trace metals and few attempts have been done to evaluate the speciation of them.

One of the most widely applied for sequential extraction procedures was proposed more than 25 years ago by Tessier et al.(1979). It is now widely recognized that the toxicity and the mobility of trace metals are depending on their geochemical forms and on their binding state. The identification of the main binding sites and phase associations of trace metals in sediments helps in understanding geochemical processes and to evaluate the remobilization potential and the risks induced (Gleyzes et al., 2002).

Sequential extraction procedures are designed to isolate specific fractions of sediment by successively attacking the sample with chemical reagents and analysis the resulting supernatant (Krye et al., 2003).

A large number of researchers have used principal component analysis (PCA) in the evaluation of environmental data (Zitko, 1994; Soares et al., 1999; Rubio, 2000; El-Iskandarani et al., 2003). Multivariate data analysis techniques have been used in eco-toxicology (Sparks et al., 1999; De Bartolomeo et al., 2004). This technique explains the most relevant information about the relationships among the anthropogenic trace metal contamination of various environments.

The main objective of this study is to examine the sediment matrices and their binding fractions to trace metals $(\mathrm{Fe}, \mathrm{Mn}, \mathrm{Zn}, \mathrm{Cu}, \mathrm{Cd}$, $\mathrm{Pb}, \mathrm{Cr}, \mathrm{Co}$ and $\mathrm{Ni}$ ). 


\section{Study area}

\section{MATERIAL AND METHODS}

Lake Manzala is the largest Nile Delta lagoon, has an area of about $670 \mathrm{~km}^{2}$. The lake is connected with the Mediterranean sea through Boughaz El-Gamil, lying to the west of Port Said City. The lagoon is shallow with depth less than $1 \mathrm{~m}$ and it is very important for fish production in Egypt. It lies between longitude $31^{\circ} 45^{\circ}$ and $32^{\circ} 15^{\circ}$ and latitude $31^{\circ} 00^{\circ}$ and $31^{\circ} 35^{\circ} \mathrm{N}$ (Fig. 1).

\section{Sampling and analysis}

Twelve surface sediment samples were collected during summer, 2004 from Lake Manzala, covering the whole area under investigation (Fig. 1) by van veen grab sampler. Samples from each site were divided into two subsamples, then homogenized by mixing and kept in clean plastic containers. Samples were stored, frozen until analysis.

A sub-sample was taken to determine chemical and physical characteristics of the sediments such as grain size distribution, total organic matter and calcium carbonate contents. Wet sieving was carried out to define grain size distribution. The total organic carbon was determined as percentage loss of weight of dried sediment sample after ignition for 24 hours at $550^{\circ} \mathrm{C}$ (Dean, 1974).

The total concentrations of trace metals were determined according to Oregioni and Aston (1984); $0.2 \mathrm{~g}$ of dried sample was digested using a mixture of nitric, perchloric and hydrofluoric acids in a previously cleaned and dried Teflon beaker, then evaporated to near dryness at $80^{\circ} \mathrm{C}$. After complete digestion, the residue was transferred to $25 \mathrm{ml}$ volumetric flask with $0.1 \mathrm{M} \mathrm{HCl}$. The total concentrations of trace metals and their fractions were measured using A.A.S. (Perkin Elmer model 373).

The sequential extraction scheme of Tessier (1979) was performed (Fig. 2). In this procedure, bubbling nitrogen prior to contact with samples deoxygenated the chemical extracts of the first step. The tubes were closed with screw-caps during mechanical shaking and centrifugation. A cheiator (10 mg EDTA) was added to the ammonium and sodium acetate extracts to prevent precipitation of metals during storage in the refrigerator. Acidification of these solutions were found to be inadequate due to precipitation of humic acids leached by the first two steps (Kersten \& Forstner, 1987). 


\section{Quality control studies}

Two natural samples were analyzed in duplicate in each of six batches of samples after spiking by a known concentration from the standard reference material. The same two natural samples were analyzed without spiking. The highest and lowest percentages of recovery for spiked samples were used to determine the accuracy. The results ranged between 90 and $110 \%$, while precision was agreed to be within $10 \%$. Table (1) illustrates the concentrations for different metals in the reference materials. The variation coefficients were $4.6 \%$ for $\mathrm{Fe} ; 7.3 \%$ for $\mathrm{Mn}$; $5.2 \%$ for $\mathrm{Cu} ; 7.1 \%$ for $\mathrm{Zn} ; 6.2$ for $\mathrm{Pb} ; 7.6 \%$ for $\mathrm{Cd}$.

\section{Statistical analysis}

Correlation matrix and principal component analysis (PCA) were carried out on the data set of trace metals among the five fractions, to describe the behavior and the association of the metals in the present study.

\section{Chemical properties of the sediments}

\section{RESULTS AND DISCUSSION}

The relative percentage of organic matter, $\mathrm{CaCO}_{3}$ and graine size distribution of Lake Manzala sediments are shown in Table la. The amounts of organic matter were relatively high in the sediment samples, its content ranged from $2.07 \%$ (Stations $\mathrm{XX}$ and XI.) to $8.96 \%$ (station XII ). The organic matter distribution is affected by its rate oxidation and the amount of wastewater drainage through the drains located in the southern part of the Lake. The carbonate content ranged between $15.7 \%$ at St. XI and $67.8 \%$ at St.IV. It is clear from the sediments analysis of the Lake that the levels of $\mathrm{CaCO}_{3}$ were higher in the eastern and western regions. The sediments type was sandy loam at most stations and clay at stations X and XII. The lake sediments were mixed with shells and shells fragment which constitute significant part of the sediments

Tables (3-11) show the values of a total concentration of nine trace metals ( $\mathrm{Fe}, \mathrm{Mn}, \mathrm{Cu}, \mathrm{Zn}, \mathrm{Pb}, \mathrm{Cd}, \mathrm{Cr}, \mathrm{Ni}$ and $\mathrm{Co}$ ) which were accumulated in the sediments of Lake Manzala. The levels of total trace metals in the sediments of the investigated area revealed significant variations. The values of these metals were in the range 9184-11828; 309$1627 ; 20-101 ; 275-491 ; 24-83 ; 1.3-2.5,28-93 ; 26-79$ and $19-54 \mu \mathrm{g} / \mathrm{g}$ for $\mathrm{Fe}, \mathrm{Mn}, \mathrm{Cu}, \mathrm{Zn}, \mathrm{Pb}, \mathrm{Cd}, \mathrm{Cr}, \mathrm{Ni}$ and $\mathrm{Co} ; \mathrm{S}$ respectively. It was considered that the average values of trace metals $(\mathrm{Cr}=90, \mathrm{Ni}=68, \mathrm{~Pb}=20, \mathrm{Cd}=0.3$ in ppm) in shales materials as the background concentration for the sediment (El-Sokkary, 1990). It is clear that the sediment in the present 
study contain high amounts of metals than those background values. This may be related to the wastewater discharged through the drains which are polluted with municipals, industrial effluents and agriculture wastewater.

2. Distribution of trace metals in the sediment matrices

The relative amounts of $\mathrm{Fe}$ among different phases of surface sediments are presented in Table 3 and Fig. 3. Iron fractionation analysis revealed that $55.53 \%$ of the total $\mathrm{Fe}$ occurred in the organic fraction and $39.56 \%$ in the residual fraction. Smaller fractions are exchangeable $(0.22 \%)$, carbonate $(0.11 \%)$ and $4.69 \%$ in the $\mathrm{Fe}-\mathrm{Mn}$ oxide fraction.

The relatively high amounts of $\mathrm{Fe}$ in organic fraction at St. VII $(62.20 \%)$ are perhaps due to the relatively high contents of organic matter $(8.96 \%)$ as shown in Table 2. Data indicated that the percentage of exchangeable, carbonate and oxides fractions were few or in comparison to other fractions.

In the same context, the relative amounts of $\mathrm{Mn}$ in different phases of surface sediments samples collected from Lake Manzala are presented in Table 4 and Fig. 3. The residual fraction of $\mathrm{Mn}$ was $1051.79 \mu \mathrm{g} / \mathrm{g}$ $(64.62 \%)$ at St. IX compared to $134.59 \mu \mathrm{g} / \mathrm{g}(43.53 \%)$ at St. IV.

The high percent of residual fraction of $\mathrm{Mn}$ at St. IX reflects the predominance of physical conditions, such as sedimentation rate. This finding is similar to that given by Lyengar et al. (1981) and Shata et al., (1993).

The relative amounts of copper in different phases of surface sediments are presented in Table 5 and Fig.3. It is clear that the percentage of exchangeable fraction (F1) was few in comparison to other fractions. The percentage of Cu-carbonate fraction (F2) fluctuated between $4.44 \%$ at station III and $24.87 \%$ at station IV. Relatively high of $\mathrm{Cu}$ in the carbonate fraction at station IV may be due to the high content of carbonate with $67.80 \%$ at this location.

The Fe-Mn oxide fraction (F4) of Cu was in the range of $2.26 \mu \mathrm{g} / \mathrm{g}$ $(17.85 \%)$ at St. VIII and $19.07 \mu \mathrm{g} / \mathrm{g}(25.48 \%)$ at St. II. Shuman (1979) stated that $\mathrm{Cu}$ is mainly associated with $\mathrm{Fe}-\mathrm{Mn}$ oxides fraction in sandy soils. Kuo \& Baker (1983) reported that $\mathrm{Cu}$ is highly bound to Mn oxides. The organic fraction of $\mathrm{Cu}$ was in the range $7.36 \mu \mathrm{g} / \mathrm{g}$ at St. VIII and $29.73 \mu \mathrm{g} / \mathrm{g}$ St. II.

High concentration of $\mathrm{Cu}$ in the organic fraction at stations I, II and III may be due to the sector El-Genkah and its water was affected mainly by industrial untreated sewage and agriculture effluents discharged from Bahr El-Bakar, Ramsis and Hodous drains. 
The results also indicate that $\mathrm{Cu}$ is predominant in the residual fraction and ranged between $2.10 \mu \mathrm{g} / \mathrm{g}$ at St. IV and $57.39 \mu \mathrm{g} / \mathrm{g}$ at St. V. This is in accordance with Moussa (1984) who reported that, the chief source of $\mathrm{Cu}$ and $\mathrm{Zn}$ seems to be the lithogenic minerals.

The relative amounts of zinc among different phases of surface sediments are presented in Table 6 and Fig.4. It is clear that the percentage of exchangeable fraction (F1) was few in comparison to other fraction ranging between $2.59 \mu \mathrm{g} / \mathrm{g}$ at St. VIII and $5.34 \mu \mathrm{g} / \mathrm{g}$ at St. III.

The average values of zinc fractionation analyses revealed that $73.20 \%, 8.97 \%, 10.81 \%, 6.21 \%$ and $0.87 \%$ of the total zinc occurred in the residual, organic bound, oxide bound, carbonate bound and exchangeable bound, respectively. The Fe-Mn oxide fraction (F4) of zinc was in the range of $34.80 \mu \mathrm{g} / \mathrm{g}(8.42 \%)$ at St. VII and $52.05 \mu \mathrm{g} / \mathrm{g}$ $(13.82 \%)$ at St. VI. Davis \& Leckie (1973) reported that amorphous sesquioxides have greater ability to retain the heavy metals to their specific surface area. Zinc is absorbed by oxides as well as being occulded in the structure. The similarity between the atomic radius of $\mathrm{Zn}$ and $\mathrm{Fe}$ makes their exchange possible. The residual fraction of $\mathrm{Zn}$ reached a maximum of $363.94 \mu \mathrm{g} / \mathrm{g}(74.16 \%)$ at St. XII: This reflects the predominance of physical conditions such as sedimentation rate. This finding is similar to that given by Lyengar et al. (1981) and Shata et al. (1993).

The relative amounts of lead among different phases of surface sediment are presented in Table 7 and Fig.4. It is clear that the distribution of $\mathrm{Pb}$ in the exchangeable fraction is limited to a few percent. Mahmoud (1994) showed that the percentage of exchangeable of $\mathrm{Pb}$ is few or negligible in sediment in comparison to other fractions. The distribution of $\mathrm{Pb}$ bound to carbonate was minimum at St. II $(2.72 \mu \mathrm{g} / \mathrm{g}$; $6.84 \%)$ compared to a maximum of $10.02 \mu \mathrm{g} / \mathrm{g}$ (17.97\%) recorded at St. $\mathrm{XII}$. However, the percentage of oxide and organic fractions of $\mathrm{Pb}$ were in the range $2.76-15.60 \%$ and $14.58-31.25 \%$ respectively.

It is clear that the residual fraction $\mathrm{Pb}$ reached a maximum of 55.47 $\mu \mathrm{g} / \mathrm{g}(66.67 \%)$ at St. VIII and a minimum of $9.15 \mu \mathrm{g} / \mathrm{g}(37.13 \%)$ at St. IV. Pardo et al. (1990) showed that the greater percentage of this fraction metal particulates means a smaller or less dangerous pollution effect. This inactive phase corresponds to a lattice bound metal, which can not be remobilized at least under normal polluting circumstances.

The relative amounts of $\mathrm{Cd}$ among different phases of surface sediment are presented in Table 8 and Fig. 4. Cadmium fractionation 
analyses revealed that high average value of $\mathrm{Cd}$, reached to $32.00 \%$ of the total $\mathrm{Cd}$ occurred in the carbonate fraction (F2) and $28.51 \%$ in the oxide fractions. Similar fractions are found in the exchangeable (12.31\%), organic bound $(12.41 \%)$ and the residual fraction $(15.80 \%)$. The relatively high percentage of $\mathrm{Cd}$ occurred as carbonate fraction especially at stations XI and I (44.38 and $39.45 \%$, respectively). This is in accordance with Förstner \& Whittmann (1983) who stated that the occurrence of $\mathrm{Cd}$ in sediments is mainly related to the formation of $\mathrm{CdCO}_{3}$. High percentage of $\mathrm{Cd}$ was recorded as $\mathrm{Fe}-\mathrm{Mn}$ oxides fractions (F3), particularly at St. XII (52.23\%). On the other hand, the organic fraction (F4) shows high percentage at St. II (24.86\%). This is mainly related to affinity of cadmium to form $\mathrm{CdS}$ precipitate especially at this station which is affected by drainage water discharged from Bahr ElBakar drain.

The amounts of $\mathrm{Cr}, \mathrm{Ni}$ and $\mathrm{Co}$ among different phases of surface sediments are presented in Tables 9,10 and 11 , respectively. The relative percentage of these fractions is recorded in Fig. 5. $\mathrm{Cr}, \mathrm{Ni}$ and $\mathrm{Co}$ fractionation revealed that relatively high percentage of the total $\mathrm{Cr}, \mathrm{Ni}$ and $\mathrm{Co}$ occurred in the organic fractions $(42.61,39.00$ and $37.53 \%$, respectively) and residual fractions $(29.36,32.81$ and $32.35 \%$ respectively). Smaller fractions are exchangeable 1.08, 3.04 and 2.79 for $\mathrm{Cr}, \mathrm{Ni}$ and $\mathrm{Co}$ metals respectively.

Relatively high amounts of $\mathrm{Cr}$ and $\mathrm{Co}$ in the organic fractions (56.81 and $52.85 \%$ ) were recorded at stations $\mathrm{V}$ and $\mathrm{X}$, may be due to high amount of organic matter at these stations $(6.31 \%$ for St. V and $5.86 \%$ for St. X).

\section{Statistical analysis}

\subsection{Correlation Matrix}

The behavior of the nine trance metals ( $\mathrm{Fe}, \mathrm{Mn}, \mathrm{Cu}, \mathrm{Zn}, \mathrm{Pb}, \mathrm{Cd}, \mathrm{Cr}$, $\mathrm{Ni}$ and $\mathrm{Co}$ ) in the sedimentary five fractions could be known by performing correlation matrix (Tables 12 a-e).

As shown in Table 12, the correlation matrix of trace metals bounded to the exchangeable fraction revealed significant correlation between $\mathrm{Cu}$ Exch. and Mn-Exch. ( $=0.59$ ) and between $\mathrm{Co}-$ Exch and $\mathrm{Pb}-$ Exch (0.62). The results of carbonate fraction (Table 12b) showed significant correlation between Ni-Carb. with both Fe-Carb. $(r=0.59)$ and Zn-Carb. $(r=0.71)$. Also, significant correlation between Cd-carb. with both CoCarb. $(r=0.56)$ and Cu-Carb. $(r=0.58)$. The correlation matrix of trace metal bounded to $\mathrm{Fe}-\mathrm{Mn}$ oxide fraction (Table 12c) showed significant 
relationship between Fe-Oxide and $\mathrm{Cr}$-oxide $(r=0.67)$ and between $\mathrm{Cu}$ oxide with both $\mathrm{Cd}$-oxide $(-0.64)$ and $\mathrm{Ni}$-oxide $(r=0.60)$. In the organic fraction (Table 12d), the results showed significant correlation between $\mathrm{Cu}-\mathrm{OM}$ with both $\mathrm{Fe}-\mathrm{OM}$ and $\mathrm{Cd}-\mathrm{OM}$ fraction $(r=0.62$ and 0.76 , respectively). The correlation between Cd-OM and Ni-OM was $r=0.77$ and between Fe-OM and Mn-OM was $F=0.61$. The correlation matrix of metals in the residual fraction (Table 12e) revealed significant correlation between Cd-Res and $\mathrm{Zn}-\operatorname{Res}(r=-0.59)$ and between Co-Res and $\mathrm{Cu}-\mathrm{Res}$ $(r=0.67)$.

The significant correlations between any two of trace metals binding fractions in the present study indicate that these metals may be discharged from the same source of pollution. The interpretation of the relationship between any two metals may be related to several main factors which are the stability constants of trace metal complexation reactions, the input of trace metals into water bodies; the quantities of ligand which refer to the binding sites (Tessier et al. 1985 ; Yu et al., 2001).

\subsection{Principal component analysis (PCA)}

The principal component analysis in the present study was performed to obtain more information about the relationships among trace metals in the binding fractions. The PCA of the metals in the five binding fractions are shown in Table 13. In the case of exchangeable fraction, F1, four components have been extracted, they accounted for $78.5 \%$ of the variance in the original data (Table 13). The plot of loadings of the components were $\mathrm{PCl}$, which associated with $\mathrm{Cu}, \mathrm{Mn}$ and $\mathrm{Ni}$, the $\mathrm{PC}_{2}$ showed the polluted signal of $\mathrm{Pb}$ and $\mathrm{Co}$, the $\mathrm{PC}_{3}$ gives the signal of pollution by $\mathrm{Cd}$ and $\mathrm{Cr}$ and the finally $\mathrm{PC}_{4}$ associated with $\mathrm{Fe}, \mathrm{Cu}$ and $\mathrm{Zn}$.

The principal component analysis of carbonate fraction(F2), was recorded in Table 13. Four components have been extracted, together they account for $81.8 \%$ of the variability in the original data. The $\mathrm{PC}_{1}$ was associated with $\mathrm{Cu}, \mathrm{Cd}$ and $\mathrm{Co}$ and the $\mathrm{PC}_{2}$ was associated with $\mathrm{Mn}$ and $\mathrm{Pb}$, while the $\mathrm{PC}_{3}$ and $\mathrm{PC}_{4}$ were associated with $\mathrm{Fe}, \mathrm{Cr}, \mathrm{Zn}$ and $\mathrm{Ni}$, respectively.

The PCA was applied on the results of trace metals associated with the oxide-fraction (lithogenic form, $F_{3}$ ). Four components whose eigenvalues were higher than 1 , accounted for a cumulative variance of $78.2 \%$ (Table 13), $\mathrm{PC}_{1}$ represent $33.1 \%$ of the data variance was associated with $\mathrm{Cu}$ and $\mathrm{Ni}, \mathrm{PC}_{2}$ represented $18.9 \%$ of the variance was associated with $\mathrm{Zn}$, while the $\mathrm{PC}_{3}$ was $14.1 \%$ of the variance associated 
with $\mathrm{Fe}, \mathrm{Zn}$ and $\mathrm{Cd}$ and finally $\mathrm{PC}_{4}$ (12\% of the variance) associated with $\mathrm{Mn}, \mathrm{Pb}, \mathrm{Cr}$ and $\mathrm{Co}$.

The plot of loading of the components in the organic fraction gives a distribution of the metals into three components. $\mathrm{PC}_{1}$ was associated with $\mathrm{Fe}, \mathrm{Mn}, \mathrm{Cu}, \mathrm{Pb}$ and $\mathrm{Co}$; they are mainly related to the anthropogenic materials and reflect the complexing nature of the organic matter, seqarate group is formed by $\mathrm{Cr}$, this is interpreted as an anthropogenic element that is not forming part of organo-metalic compounds (Rubio et al. 2000). $\mathrm{PC}_{2}$ of this fraction showed the polluted signal of $\mathrm{Cr}, \mathrm{Cd}$ and $\mathrm{Ni}$ and finally $\mathrm{PC}_{3}$ gives the signal of pollution by $\mathrm{Zn}$.

The application of PCA on the data of trace metals binding to the residual fraction (Table 13) explaining only the first three components ( $66.5 \%$ of the variance). The $\mathrm{PC}_{1}$ of this fraction represent $30.5 \%$ of the variance and associated with $\mathrm{Ni}$ and $\mathrm{Cr}$ while $\mathrm{PC}_{2}(20.6 \%$ of the variance) associated with $\mathrm{Mn}, \mathrm{Cu}, \mathrm{Pb}$ and $\mathrm{Cd}$. On the other hand the $\mathrm{PC}_{3}$ represent $15.4 \%$ of variance and associated with $\mathrm{Fe}, \mathrm{Cu}$ and $\mathrm{Zn}$.

\section{CONCLUSION}

Sequential extraction results have been proved to be useful to - distinguish between anthropogenic and geochemical sources of most metal species in sediment. The high proportion of metals in the residual phase and the generally low levels of extractable metals indicate that the sediments were relatively unpolluted. It was concluded that the capacity of the sediment to function as a sink for heavy metals was sufficient. Redistribution phenomena during the extraction were not evaluated. The forgoing discussion implies the following points: i) high content of $\mathrm{Cu}_{\text {, }}$ $\mathrm{Zn}, \mathrm{Pb}$ and $\mathrm{Mn}$ are formed in the residual fractions reflecting geochemical origin, ii) the relatively high amount of $\mathrm{Cr}, \mathrm{Ni}, \mathrm{Co}$ and $\mathrm{Fe}$ in the organic fraction, iii) high content of $\mathrm{Cd}$ was found in the carbonate fraction and iv) high levels of $\mathrm{Cu}, \mathrm{Zn}, \mathrm{Pb}, \mathrm{Cr}, \mathrm{Ni}, \mathrm{Co}, \mathrm{Fe}$ and $\mathrm{Mn}$ in the three steps, $\mathrm{F}_{1}$, $F_{2}$ and $F_{3}$ may be related to the non-lithogenous origin, indicating that these metals were incorporated into the mineral phase, and are therefore of natural geochemical origin. 


\section{REFERENCES}

Adams, V. (1990). Water and Wastewater Examination Manual. Lewis publishers, USA, $2457 \mathrm{pp}$.

Brannon, J. M.; Engler, R. M.; Rose, J. R.; Hunt, P. G. and Smith, I. (1977). Dredged material research program. Technical Report D76-7 Office, Chief of Engineers, U.S. Army, Washington, D.C. $20314 p p$.

Davis, J. A. and Leckie, J. O. (1978). Effect of adsorbed complexing ligands on trace metals uptake by hydrousoxides. Environ. Sci., Technol., 12: 1309-15.

Dean W. E. (1974). Determination of carbonate and organic matter in calcareous sediments and sedimentary rocks by loss ignition comparison with other methods J. Sedimentry Petrology, 44: 242.

DeBartolomeo, A.; Poletti, L.; Sanchini, G.; Sebastiani, B. and Morozzi, G. (2004). Relationship among parameters of Lake polluted sediments evaluated by multivariate statistical analysis. Chemosphere, 55: 1323-1329.

El-Iskandarani, M.; Nasr, S.; Okbah, M. and Jensen, A. (2003). Principal components analysis for quality assessment of the Mediterranean coastal water of Egypt,65 (2): 69-86.

Forstner, U. and. Wittmann, G. (1983). Metal pollution in the aquatic environment, springer Verlag Berlin Heidelberg, New York, Tokyo, 486 pp.

Gleyzes, C.; Tellier, S. and Astruc, M. (2002). Fractionation studies of trace elements in contaminated soils and sediments: a review of sequential extraction procedure. Trends in Analytical Chemistry, $21(6+7): 451-467$.

Kersten, M. and Förstner, U. (1987). Effect of sample pretreatment on the reliability of solid speciation data of heavy metals: implications for the study of early digenetic processes. J. Marine Chemistry., 22: 299. 
Krye, K. A.; Murray, R. W. and Murray, D. W. (2003). Elemental fractionation of $\mathrm{Si}, \mathrm{Al}, \mathrm{Ti}, \mathrm{Fe}, \mathrm{Ca}, \mathrm{Mn}, \mathrm{P}$ and $\mathrm{Ba}$ in five marine sedimentary reference materials: results from sequential extractions. Analytica chemica Acta, 487: 117-128.

Kuo, S. and Baker, A. B. (1983). Distribution and forms of copper, zinc, cadmium, iron and manganese in soils near a copper smelter, $\mathrm{J}$. Soil Sic., 135: 101-9.

Layengar, S. S.; Martens, D.C. and Miller, W. P. (1981). Distribution and plant availability of soil zinc fractions. Soil Sci. Am. J., 45: 735-9.

Mahmoud, W. M. A. (1994). Chemical investigation on lead in the western harbour of Alexandria, M.Sc. Thesis, Faculty of Science, Alex. Univ. 223 pp.

Moussa, A. A. (1984). Estimation of metal pollutant levels in sediments from Lake Borollos, J. Etud. Pollut. Cannes CIESM, 5: 373-7.

Oregioni, B. and Aston, S. R. (1984). The determination of selected trace metals in marine sediments by flame atomic absorption spectrophotometry. IAEA. Monaco Laboratory Internal Report. UNEP, reference methods for marine pollution studies No. 38.

Pardo, R.; Barrado, E.; Perez, L. and Vega, M. (1990). Determination and speciation of trace metals in sediments of the Pisuerga Rive, Water Res.24: 337-343.

Rubio, B.; Nombela, M. A. and Vilas, F. (2000). Geochemistry of major and trace elements in sediments of the Ria de Vigo (NW Spain): an Assessment of metal pollution. Marine Pollution Bulletin. 40 (11):968-980.

Shata, M. A.; El-Deek, M. S. and Okbah, M. A. (1993). Fractionation of $\mathrm{Mn}, \mathrm{Fe}, \mathrm{Zn}$ and $\mathrm{Cu}$ in sediments of Khor kalabsha Lake Nasser, Egypt. Chemistry \& Ecology, 8: 89-103.

Shuman, L. M. (1979). Zinc, manganese, and copper in soil fractions, Soil Sci., 127: 10-7. 
Soares, H.M.V. M.; Boaventura, R. A. R.; Machado, A. A. S. C. and Esteves da silva, J. C. G. (1999). Sediments as monitors of heavy metal contamination in the Ave river basin (Portugal): multivariate analysis of data. Environ. Pollut, 105: 311-323.

Sparks, T. M.; Scott, W. A. and Clarks, R. T. (1999). Traditional multivariate tenchniques: Potential for use in ecoloxicology. Environ. Toxicol. Cehm. 18 (2): 128-137.

Tessier, A.; Rapin, F. and Carignan, R. (1985). Trace metals in oxic lake sediments: possible adsorption onto iron oxyhydroxides. Geochim. Cosmochim. Acta. 47: 1091-1098.

Tessier, A.; Gampbell, P. G. C. and Rissa, M. (1979). Sequential extraction procedure for the speciation of particulate trace metals. Anal. Chem., 51: 844-851.

Yu, K. C.; Tsai, L. J.; Chen, S. H. and Ho, S. T. (2001). Correlation analysis on binding behavior of heavy metals with sediment matrices. Wat. Res. 35 (10): 2417-2428.

Zitko, V. (1994). Principal component analysis in the evaluation of environmental data. Marine Pollution Bulletin. 28: 718-722. 
Table (1). The concentrations for trace metals $(\mu \mathrm{g} / \mathrm{g})$ in the references materials (MESS-3, National research of council of Canada).

\begin{tabular}{|l|c|c|}
\hline \multicolumn{1}{|c|}{ Metal } & Found & Certified \\
\hline Iron & $0.230 \pm 0.02$ & $0.236 \pm 0.017$ \\
\hline Manganese & $328 \pm 8.00$ & $324 \pm 12.0$ \\
\hline Zinc & $156 \pm 10.10$ & $159 \pm 8.0$ \\
\hline Copper & $34.2 \pm 2.53$ & $33.9 \pm 1.6$ \\
\hline Lead & $20.38 \pm 0.85$ & $21.10 \pm 0.70$ \\
\hline Cadmium & $0.20 \pm 0.08$ & $0.24 \pm 0.01$ \\
\hline Chromium & $107.0 \pm 7.03$ & $105.0 \pm 4.0$ \\
\hline Nickel & $48.10 \pm 3.10$ & $46.9 \pm 2.2$ \\
\hline Cobalt & $14.05 \pm 1.80$ & $14.4 \pm 2.0$ \\
\hline
\end{tabular}


Table 2 : Organic matter, $\mathrm{Ca} \mathrm{CO}_{3}$ contents and graine size analysis of Lake Manzalah during summer ,2005

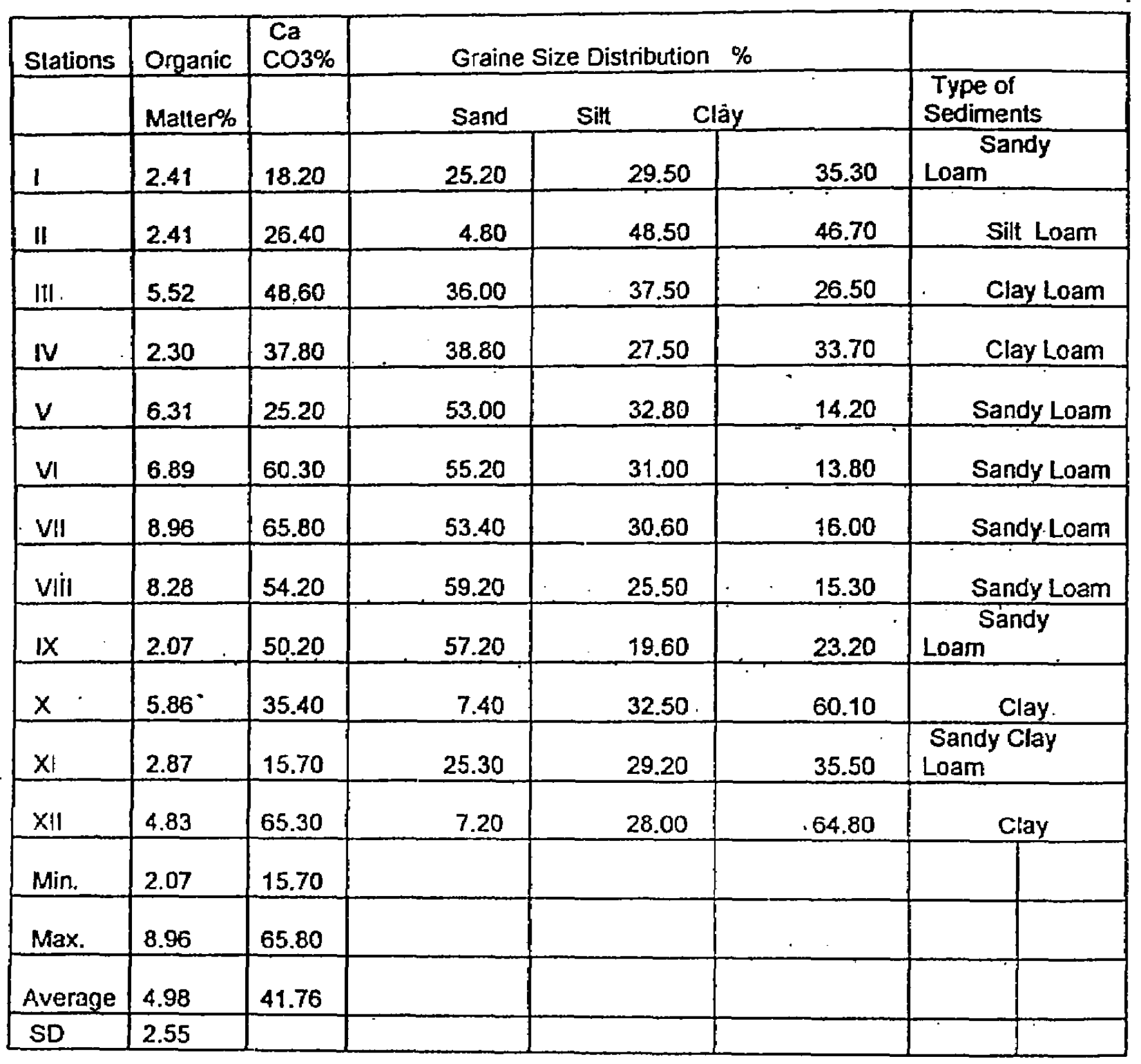


Table3: Iron concentration ( $\mu \mathrm{g} / \mathrm{g})$ in each fraction of Lake Manzalah sedim:erts

\begin{tabular}{|c|c|c|c|c|c|c|}
\hline Stations & Exchangeable & $\begin{array}{c}\text { Carbonate } \\
\text { form }\end{array}$ & $\begin{array}{c}\begin{array}{c}\text { Oxides } \\
\text { form }\end{array} \\
\end{array}$ & $\begin{array}{c}\text { Organic } \\
\text { form }\end{array}$ & $\begin{array}{c}\begin{array}{c}\text { Residuxl } \\
\text { form }\end{array} \\
\end{array}$ & Total \\
\hline & $\mu g / g$ & $\mu \mathrm{g} / \mathrm{g}$ & $\mu g / g$ & $\mu g / g$ & $\mu \mathrm{g} / \mathrm{s}$ & $\mu \mathrm{g} / \mathrm{g}$ \\
\hline I & 17.08 & 5.79 & 717.00 & 6272.12 & 4,570 & 11,582 \\
\hline II & 25.08 & 5.68 & $727.3 \pm$ & 6493.1 & 4,577 & 11,828 \\
\hline III & 12.76 & 7.03 & 687.53 & 6555.16 & 4,098 & 11,360 \\
\hline IV & 21.81 & 10.27 & 461.49 & 43.92 .92 & 4,298 & 9,184 \\
\hline$V$ & 20.32 & 35.98 & 724.96 & 6443.22 & 4,207 & 11,431 \\
\hline $\mathrm{VI}$ & 10.31 & 14.05 & +65.73 & 5521 & 4,941 & 10,952 \\
\hline VII & 31.01 & 7.56 & 193.11 & 5715.32 & 3,241 & 9,188 \\
\hline VIII & 14.86 & 1.36 & 287.35 & 5758.34 & 3,740 & 9,802 \\
\hline$I X$ & 16.96 & 8.26 & 620.09 & 0114.36 & 4,074 & $\cdot 10,834$ \\
\hline$X$ & 23.31 & 7.94 & 584.09 & 6537.76 & 4,535 & $.11,688$ \\
\hline$X I$ & 6.5 .44 & 15.60 & 372.3 .3 & 6144.52 & 4,543 & $.111,141$ \\
\hline XII & 6.91 & 9.16 & 440.17 & 6208.9 & 4,122 & 10,787 \\
\hline Average & 24.16 & 11.86 & 514.40 & 5936.06 & 4,223 & $10,77 !$ \\
\hline SD & 18.09 & 10.55 & 191.04 & 705.78 & 513.52 & 969.96 \\
\hline
\end{tabular}

Table4: Manganesc concentration $(\mu \mathrm{g} / \mathrm{g})$ in each fraction of Lake Manzalah sediments

\begin{tabular}{|c|c|c|c|c|c|c|}
\hline \multirow[t]{2}{*}{ Stations } & Exchangeable & \begin{tabular}{c|}
$\begin{array}{c}\text { Carbonatc } \\
\text { form }\end{array}$ \\
\end{tabular} & $\begin{array}{c}\text { Oxides } \\
\text { FormI }\end{array}$ & $\begin{array}{c}\text { Organic } \\
\text { form }\end{array}$ & $\begin{array}{c}\text { Residual } \\
\text { form }\end{array}$ & Total \\
\hline & $\mu \mathrm{g} / \mathrm{g}$ & $\mu g / g$ & $\mu \mathrm{g} / \mathrm{g}$ & $\mu \mathrm{kg} / \mathrm{g}$ & $\mu p / g$ & $\mu \mathrm{g} / \mathrm{g}$ \\
\hline I & 28.87 & 156.85 & 148.83 & 75.69 & 503.91 & 914.15 \\
\hline II & 37.43 & 167.73 & 184.6 & 97.7 & 525.54 & $1,013.00$ \\
\hline IiI & 30.64 & 182.76 & 184.77 & 59.1 & 543.61 & $1,000.00$ \\
\hline IV & 6.12 & 31.08 & 114.64 & 22.75 & 134.59 & 309.18 \\
\hline $\mathrm{V}$ & 11.85 & 58.38 & 179.93 & 98.1 & 304.74 & 653 \\
\hline VI & 15.52 & 154.07 & 106.09 & 97.24 & 409.16 & 782.08 \\
\hline VII & 11.47 & 87.32 & 165.25 & 62.38 & 430.76 & 757.18 \\
\hline VIII & 11.33 & 115.2 & 106.71 & 89.04 & 500.35 & 822.63 \\
\hline IX & 23.58 & $199.4 \mathrm{I}$ & 259.84 & 93.08 & $1,051.79$ & $1,627.70$ \\
\hline$x$ & 12.59 & 75.76 & 153.3 & 87.52 & 415.56 & 744.73 \\
\hline XI & 8.57 & 121.86 & 137.74 & 55.15 & 280.98 & 604.3 \\
\hline XII & 4.84 & 52 & 47.35 & 85.16 & 286.53 & 475.88 \\
\hline Average & 37.43 & 199.41 & 259.84 & 98.1 & $1,051.79$ & $1,627.70$ \\
\hline SD & 12.44 & 62.6 & 68.28 & 26.24 & 225.86 & 329.49 \\
\hline
\end{tabular}


Table 5: Copper concentration $(\mu g / g)$ in each fraction of Lake Manzalah sediments

\begin{tabular}{|c|c|c|c|c|c|c|}
\hline Stations & Exchangcable & $\begin{array}{c}\text { Carbonatc } \\
\text { form }\end{array}$ & $\begin{array}{c}\text { Oxides } \\
\text { form }\end{array}$ & $\begin{array}{c}\text { Organic } \\
\text { form }\end{array}$ & $\begin{array}{l}\text { Residual } \\
\text { form }\end{array}$ & Total \\
\hline & $\mu \mu / g$. & $\mu \varphi / g$ & $\mu \rho / g$ & $\mu g / g$ & $\mu g / g$ & $\mu g / h$ \\
\hline 1 & 0.71 & 8.10 & 17.01 & 23.13 & 49.30 & 98.25 \\
\hline II & 0.43 & 7.61 & 19.07 & 29.73 & 43.98 & 100.82 \\
\hline III & 0.12 & 4.03 & 16.24 & 27.20 & 42.85 & 90.74 \\
\hline IV & 0.16 & 5.14 & 3.02 & 10.25 & 2.10 & 20.67 \\
\hline $\mathrm{V}$ & 0.25 & 6.32 & 5.27 & 20.67 & 57.39 & 89.9 \\
\hline VI & 0.18 & 6.79 & 2.76 & 10.24 & 36.12 & 56.09 \\
\hline VI & 0.2 & 2.34 & 3.19 & 9.06 & 17.54 & 32.33 \\
\hline VIII & 0.15 & 4.74 & 2.26 & 7.36 & 13.93 & 28.44 \\
\hline$I X$ & 0.23 & 3.56 & 3.38 & 9.00 & 20.18 & 36.44 \\
\hline$x$ & 0.41 & 4.36 & 2.65 & 19.69 & 28.07 & 55.18 \\
\hline$X I$ & 0.36 & 5.17 & 2.88 & 13.65 & 22.20 & 44.26 \\
\hline 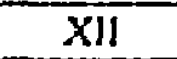 & 0.31 & 7.45 & 3.97 & 10.08 & 15.50 & 37.31 \\
\hline Average & 0.32 & 5.47 & 6.81 & 15.85 & 29.10 & 57.54 \\
\hline SD & 0.15 & 1.72 & 6.21 & 7.51 & 16.01 & 28.23 \\
\hline
\end{tabular}

Table 6: Zinc concentration ( $\mu \mathrm{g} / \mathrm{g}$ ) in each fraction of Lake Manzalah sediments

\begin{tabular}{|c|c|c|c|c|c|c|}
\hline \multirow{2}{*}{ Stations } & Exchangeable & $\begin{array}{c}\text { Carbonate } \\
\text { form }\end{array}$ & $\begin{array}{c}\text { Oxidcs } \\
\text { form }\end{array}$ & $\begin{array}{c}\text { Organic } \\
\text { form }\end{array}$ & $\begin{array}{c}\text { Residual } \\
\text { form }\end{array}$ & Total \\
\cline { 2 - 7 } & $\mu \mathrm{g} / \mathrm{g}$ & $\mu \mathrm{g} / \mathrm{g}$ & $\mu \mathrm{g} / \mathrm{g}$ & $\mu \mathrm{g} / \mathrm{g}$ & $\mu \mathrm{g} / \mathrm{g}$ & $\mu \mathrm{g} / \mathrm{g}$ \\
\hline II & 4.01 & 20.95 & 35.2 & 45.88 & 308.19 & $4 \mathrm{l4.23}$ \\
\hline III & 3.2 & 29.6 & 51 & 37.72 & 302.88 & 424.4 \\
\hline IV & 5.34 & 31.99 & 46.21 & 31.56 & 263.65 & 378.75 \\
\hline V & 2.6 & 22.89 & 47.03 & 27.42 & 174.98 & 274.92 \\
\hline VI & 3.56 & 32.52 & 35.62 & 21.12 & 274.56 & 367.38 \\
\hline VII & 3.74 & 24.37 & 52.05 & 27.51 & 269.09 & 376.76 \\
\hline VIII & 3.4 & 12.25 & 34.8 & 25.88 & 336.82 & 413.15 \\
\hline IX & 2.59 & 20.73 & 41.13 & 39.14 & 298.24 & 401.83 \\
\hline X & 2.84 & 21.93 & 35.8 & 32.29 & 309.41 & 402.37 \\
\hline XI & 3.41 & 23.09 & 49.34 & 53.83 & 340.52 & 469.61 \\
\hline XII & 2.96 & 28.37 & 35.74 & 44.71 & 337.84 & 450.07 \\
\hline Average & 3.47 & 30.68 & 36.44 & 56.72 & 363.94 & 490.74 \\
\hline SD & 0.87 & 64.58 & 41.94 & 37.26 & 294.22 & 402.13 \\
\hline
\end{tabular}


Table 7: Lead concentration ( $1 \mathrm{~g} / \mathrm{g}$ ) in each fraction of Lake Manzalah sediments

\begin{tabular}{|c|c|c|c|c|c|c|}
\hline \multirow{2}{*}{ Stations } & Exchangeable & $\begin{array}{c}\text { Carbonatc } \\
\text { form }\end{array}$ & $\begin{array}{c}\text { Oxides } \\
\text { form }\end{array}$ & $\begin{array}{c}\text { Organic } \\
\text { form }\end{array}$ & $\begin{array}{c}\text { Residual } \\
\text { form }\end{array}$ & Total \\
\cline { 2 - 7 } & $\mu \mathrm{g} / \mathrm{g}$ & $\mu \mathrm{g} / \mathrm{g}$ & $\mu \mathrm{g} / \mathrm{g}$ & $\mu \mathrm{g} / \mathrm{g}$ & $\mu \mathrm{g} / \mathrm{g}$ & $\mu \mathrm{g} / \mathrm{g}$ \\
\hline $\mathrm{I}$ & 0.27 & 3.58 & 2.97 & 10.35 & 38.75 & 55.92 \\
\hline $\mathrm{II}$ & 0.16 & 2.72 & 6.2 & 12.42 & 18.25 & 39.75 \\
\hline III & 3.47 & 4.03 & 4.75 & 15.45 & 31.55 & 59.25 \\
\hline IV & 1.65 & 4.11 & 3.36 & 6.37 & 9.15 & 24.64 \\
\hline V & 2.11 & 6.47 & 8.94 & 14.38 & 32.22 & 64.12 \\
\hline VI & 2.23 & 3.04 & 2.51 & 7.82 & 33.04 & 48.64 \\
\hline VII & 1.68 & 8.83 & 5.4 & 9.5 & 26.36 & 51.77 \\
\hline VIII & 1.77 & 9.1 & 2.3 & 14.56 & 55.47 & 83.2 \\
\hline IX & 5.12 & 5.11 & 3.2 & 4.55 & 13.22 & 31.2 \\
\hline X & 4.26 & 7.52 & 2.5 & 11.92 & 15.6 & 41.8 \\
\hline XI & 2.71 & 5.02 & 3.6 & 5.3 & 17.23 & 33.86 \\
\hline$X I I$ & 2.48 & 10.02 & 6.26 & 12.8 & 24.21 & 55.77 \\
\hline Averagc & 2.37 & 5.88 & 4.52 & 10.39 & 27.12 & 49.84 \\
\hline SD & 1.6 & 2.64 & 2.24 & 3.91 & 14.59 & 18.2 \\
\hline
\end{tabular}

Table 8: Cadmium concentration $(\mu g / g)$ in each fraction of Lake Manzalah sediments

\begin{tabular}{|c|c|c|c|c|c|c|}
\hline \multirow{2}{*}{ Stations } & Exchangeable & $\begin{array}{c}\begin{array}{c}\text { Carbonatc } \\
\text { form }\end{array} \\
\end{array}$ & $\begin{array}{c}\text { Oxides } \\
\text { form }\end{array}$ & $\begin{array}{c}\text { Organic } \\
\text { form }\end{array}$ & $\begin{array}{c}\text { Residual } \\
\text { form }\end{array}$ & Total \\
\hline & $\mu \mathrm{g} / \mathrm{g}$ & $\mu \mathrm{g} / \mathrm{g}$ & $\mu \mathrm{g} / \mathrm{g}$ & $\mu \mathrm{g} / \mathrm{g}$ & $\mu \mathrm{g} / \mathrm{g}$ & $\mu \mathrm{dg}$ \\
\hline 1 & 0.24 & 0.50 & 0.12 & 0.24 & 0.17 & 1.27 \\
\hline II & 0.18 & 0.52 & 0.21 & 0.45 & 0.45 & 1.81 \\
\hline III & 0.21 & 0.61 & 0.24 & 0.27 & 0.55 & 1.88 \\
\hline IV & 0.22 & 0.57 & 0.35 & 0.23 & 0.31 & 1,68 \\
\hline v & 0.23 & 0.46 & 0.74 & 0.18 & 0.37 & 1.98 \\
\hline V] & 0.24 & 0.43 & 0.76 & 0.14 & 0.38 & 1.95 \\
\hline VII & 0.19 & 0.64 & 0.50 & 0.22 & 0.09 & 1,64 \\
\hline VIII & 0.14 & 0.35 & 0.63 & 0.09 & 0.44 & 1.65 \\
\hline IX & 0.24 & 0.91 & 0.97 & 0.12 & 0.27 & 2.51 \\
\hline$x$ & 0.23 & 0.58 & 0.42 & 0.16 & 0.14 & 1.54 \\
\hline XI & 0.18 & 0.65 & 0.28 & 0.20 & 0.15 & 1.46 \\
\hline XII & 0.17 & 0.41 & 0.82 & 0.13 & 0.04 & 1.57 \\
\hline Averagc & 0.21 & 0.55 & 0.50 & 0.20 & 0.28 & 1.75 \\
\hline SD & 0.03 & 0.15 & 0.28 & 0.09 & 0.16 & 0.31748 \\
\hline
\end{tabular}


Table 9: Chromium concentration ( $\mu \mathrm{g} / \mathrm{g}$ ) in each fraction of Lake Manzalalt sediments

\begin{tabular}{|c|c|c|c|c|c|c|}
\hline \multirow{2}{*}{ Stations } & Exchanfeable & $\begin{array}{l}\text { Carbonatc } \\
\text { form }\end{array}$ & $\begin{array}{l}\text { Oxides } \\
\text { form }\end{array}$ & $\begin{array}{c}\text { Organic } \\
\text { form }\end{array}$ & $\begin{array}{l}\text { Residual } \\
\text { form }\end{array}$ & Total \\
\hline & $\mu \mathrm{\mu} / \mathrm{g}$ & $\mu g / g$ & $\mu \mathrm{g} / \mathrm{g}$ & $\mu \mathrm{g} / g$ & $\mu \omega^{\prime} h$ & $\mu g / g$ \\
\hline $\mathrm{I}$ & 0.92 & 2.21 & 13,37 & 23.7 & 6.3 & 46.5 \\
\hline 91 & 1.89 & 1.60 & 14.92 & 21.9 & 13.83 & 54.2 \\
\hline III & 0.74 & 2.16 & 19.73 & 28.54 & 13.4 & 64.57 \\
\hline IV & 0.61 & 1.61 & 7.57 & 15.05 & 3.56 & 28.4 \\
\hline $\mathrm{V}$ & 2.16 & 2.34 & 16.09 & 41.8 & 11.19 & 73.58 \\
\hline$\overline{\mathrm{VI}}$ & 0.79 & 1.38 & 23.44 & 26.54 & 40.85 & 93 \\
\hline VII & 1.06 & 1.86 & 13.86 & 34.51 & 31.89 & 83.18 \\
\hline VIII & 1.38 & 1.33 & 12.2 & 23.44 & 32.48 & 70.83 \\
\hline $\mathrm{LX}$ & 1.77 & 1.28 & 21.5 & 33.85 & 29.14 & 87.54 \\
\hline $\bar{x}$ & 1.1 & 0.97 & 12.89 & 32.12 & 37.64 & 84.72 \\
\hline $\mathrm{X} 1$ & 0.6 & 1.51 & 21.59 & 41.52 & 27.86 & 93.08 \\
\hline$\overline{\mathrm{XII}}$ & 1.11 & 0.94 & 22.46 & $3+.87$ & 24.6 & 83.98 \\
\hline Average & 1.21 & 1.61 & 16.47 & 29.62 & 22.65 & 70.36 \\
\hline SD & 0.55 & $0.4^{\prime \prime}$ & 5.37 & 8.79 & 13.18 & 32.81 \\
\hline
\end{tabular}

Tabic 10: Nickel concentration $(\mu \mathrm{g} / \mathrm{g})$ in each fraction of Lake Manzalah sediments

\begin{tabular}{|c|c|c|c|c|c|c|}
\hline \multirow{2}{*}{ Slations } & Exchangeablc & $\begin{array}{c}\text { Carbonalc } \\
\text { form }\end{array}$ & $\begin{array}{c}\text { Oxides } \\
\text { form }\end{array}$ & $\begin{array}{c}\text { Organic } \\
\text { form }\end{array}$ & $\begin{array}{c}\text { Residual } \\
\text { form }\end{array}$ & Total \\
\hline & $\mu \mathrm{g} / \mathrm{g}$ & $\mu \mathrm{g} / \mathrm{g}$ & $\mu \mathrm{g} / \mathrm{g}$ & $\mu \mathrm{g} / \mathrm{g}$ & $\mu \mathrm{g} / \mathrm{g}$ & $\mu \mathrm{g} / \mathrm{g}$ \\
\hline $\mathrm{I}$ & 2.18 & 2.57 & 10.72 & 29.11 & 24.92 & 69.5 \\
\hline $\mathrm{II}$ & 1.8 & 11.09 & 12.6 & 30.47 & 22.89 & 78.85 \\
\hline $\mathrm{III}$ & 0.86 & 3.44 & 8.53 & 22.41 & 38.16 & .73 .4 \\
\hline $\mathrm{IV}$ & 1.38 & 1.86 & 6.71 & 22.38 & 29.62 & 61.95 \\
\hline $\mathrm{V}$ & 1.95 & 12.2 & 4.86 & 7.88 & 1.79 & 28.68 \\
\hline $\mathrm{VI}$ & 0.94 & 1.5 & 4.37 & 18.03 & 17.06 & 41.9 \\
\hline $\mathrm{VII}$ & 1.29 & 1.89 & 14.28 & 24.85 & 9.49 & 51.8 \\
\hline $\mathrm{VIII}$ & 0.78 & 1.59 & 1.64 & 12.17 & 9.77 & 25.95 \\
\hline $\mathrm{IX}$ & 1.32 & 2.46 & 5.79 & 14.15 & 4.58 & 28.3 \\
\hline $\mathrm{X}$ & 1.53 & 1.89 & 4.93 & 16.47 & 24.43 & 49.25 \\
\hline $\mathrm{XI}$ & 0.89 & 9.73 & 4.51 & 22.41 & 22.31 & 59.85 \\
\hline $\mathrm{XII}$ & 0.83 & 7.55 & 5.82 & 14.44 & 12.56 & 41.2 \\
\hline Average & 1.34 & 5.11 & 7.19 & 19.51 & 18.4 & 51.1 \\
\hline SD & 0.5 & 4.69 & 4.1 & 7.45 & 11.81 & 18.98 \\
\hline
\end{tabular}


Table 11: Cobalt concentration ( $\mu \mathrm{g} / \mathrm{g})$ in cach fraction of Lake Manzalah sediments

\begin{tabular}{|c|c|c|c|c|c|c|}
\hline \multirow[t]{2}{*}{ Stations } & Exchangeablc & $\begin{array}{l}\text { Carbonalc } \\
\text { form }\end{array}$ & $\begin{array}{l}\text { Oxides } \\
\text { form }\end{array}$ & $\begin{array}{c}\text { Organic } \\
\text { form }\end{array}$ & $\begin{array}{c}\text { Residual } \\
\text { form }\end{array}$ & Total \\
\hline & $\mu \mathrm{g} / \mathrm{L}$ & $\mu g / g$ & $\mu g / g$ & $\mu \mathrm{g} / \mathrm{g}$ & $\mu \mathrm{g} / \mathrm{g}$ & $\mu g / g$ \\
\hline I & 0.32 & 2.01 & 3.2 & 8.11 & 23.71 & 37.35 \\
\hline 11 & 0.59 & 3.5 & 4.11 & 16.08 & 30.4 & 54.68 \\
\hline III & 0.88 & 3.98 & 5.8 & 17.31 & 14.66 & 42.63 \\
\hline IV & 0.24 & 3.37 & 3.54 & 6.24 & 5.56 & 18.95 \\
\hline $\mathrm{v}$ & 0.12 & 2.52 & 4.23 & 10.16 & 11.17 & 28.2 \\
\hline $\mathrm{VI}$ & 0.12 & 2.26 & 3.36 & 15.94 & 12.3 & 33.98 \\
\hline $\mathrm{Vt}$ & 0.23 & 2.84 & 5.89 & 9.36 & 4.63 & 22.95 \\
\hline VIII & 0.25 & 3.7 & 6.9 & 10.77 & 10.58 & 32.2 \\
\hline IX & $1 .+2$ & 4.47 & 7.43 & 14.76 & 2.52 & 30.6 \\
\hline $\bar{x}$ & 2.44 & 2.03 & 6.64 & 24,38 & 10.64 & 46.13 \\
\hline$X I$ & 1.5 & 3.33 & 13.4 & 10.47 & 5.38 & 34.08 \\
\hline $\mathrm{XII}$ & 2.2 & 1.31 & 7.2 & 9.88 & 5.94 & 26.53 \\
\hline Average & 0.92 & 2.94 & 6.31 & 13.15 & 12.17 & 34.42 \\
\hline SD & 0.87 & 1.02 & 3.26 & 5.71 & 9.19 & 11.23 \\
\hline
\end{tabular}


Table (12). Correlation matrix of trace-metal bounded to a) Exchangeable b) Carbonate c) FeMn oxides form d) Organic form e) Residual form; Manzalah Lake sediments (No. $=12$, Significance at $<0.05$ )

\begin{tabular}{|c|c|c|c|c|c|c|c|c|c|}
\hline a) & Fe-Exch & Mn-Exch & Cu-Exch & Zn-Exch & Pb-Exch & Cd-Exch & Cr-Exch & Ni-Exch & Co-Exch \\
\hline Fe-Exch & 1.00 & & & & & & & & \\
\hline Mn-Exch & & 1.00 & & & & & & & \\
\hline Cu-Exch & & 0.59 ; & 1.00 & & & & & & \\
\hline Zn-Exch & & & & 1.00 & & & & & \\
\hline $\mathrm{Pb}$-Exch & & & & & 1.00 & & & & \\
\hline Cd-Exch & & & & & & 1.00 & & & \\
\hline Cr-Exch & & & & & & & 1.00 & & \\
\hline Ni-Exch & $\because$ & & & & & & & 1.00 & \\
\hline Co-Exch & & & & & 0.62 & & & & 1.00 \\
\hline b) & Fefiurb & Mn-C:arb & Cu-Carb & Zn-Carh & Pb-Curb & Cd-Curb & Cr-Curb & Ni-Curb & Co-Carb \\
\hline Fe-Carb & 1.00 & & & & & & & & \\
\hline Mn-Carb & & 1.00 & & & & & & & \\
\hline Cu-Carb & & $-\ldots$ & $1 \cap n$ & & & 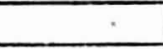 & & & \\
\hline Zn-Carb & & & & 1.00 & & & & & \\
\hline Pb-Carb & & & & & 1.00 & & & & \\
\hline Cd-Carb & & & -0.58 & & & 1.00 & & & \\
\hline Cr-Carb & & 5 & & & & & 1.00 & & \\
\hline $\mathrm{Ni}$ - Carb & 0.59 & & . & 0.71 & . & & & 1.00 & \\
\hline Co-Carb & & & & & & 0.56 & & & 1.00 \\
\hline c) & Fe-Ox. & Mn-Ox. & $\mathrm{Cu}-\mathrm{Ox}$. & Zn-Ox. & $\mathrm{Pb}-\mathrm{Ox}$ & Cd-Ox. & $\mathrm{Cr}-\mathrm{Ox}$ & Ni-Ox. & Co-Ox. \\
\hline $\mathrm{Fe}-0 \mathrm{x}$. & 1.00 & & & & & & & & \\
\hline Mn-Ox. & & 1.00 & & & & & & & \\
\hline Cu-Ox. & & & 1.00 & & & & & & \\
\hline Zn-0x. & . & $\cdot$ & & 1.00 & $\cdot$ & $\%$ & & & \\
\hline $\mathrm{Pb}-0 \mathrm{x}$. & & - & & & 1.00 & & . & & \\
\hline cd-ox. & & & -0.64 & & & 1.00 & & & \\
\hline Cr-Ox. & 0.67 & & & & & i & 1.00 & & \\
\hline $\mathrm{Ni}-\mathrm{Ox}$. & & & 0.60 & & & & & 1.00 & \\
\hline Co-0x. & & & & & & & & & 1.00 \\
\hline d). & $\mathrm{Fe}-\mathrm{OM}$. & $\mathrm{Mn}-\mathrm{OM}$ & $\mathrm{Cu}-\mathrm{OM}$ & $\mathrm{Zn}-\mathrm{OM}$ & $\mathrm{Pb}-\mathrm{OM}$ & Cd-OM & $\mathrm{Cr}-\mathrm{OM}$ & $\mathrm{Ni}-\mathrm{OM}$ & Co-OM. \\
\hline $\mathrm{Fe} \cdot \mathrm{OM}$ & 1.00 & & & & & & & & \\
\hline $\mathrm{Mn}-\mathrm{OM}$. & 0.61 & 1.00 & & & & & & & \\
\hline $\mathrm{Cu}-\mathrm{OM}$ & 0.62 & & 1.00 & & & & & & \\
\hline $\mathrm{Zn}-\mathrm{OM}$ & & & & 1.00 & . & & & & 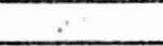 \\
\hline $\mathrm{Pb}-\mathrm{OM}$ & & & & & 1.00 & & & & \\
\hline Cd-OM & & 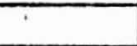 & 0.76 & & . & 1.00 & & & \\
\hline $\mathrm{Cr}-\mathrm{OM}$ & & & & & & & 1.00 & & \\
\hline $\mathrm{Nl}-\mathrm{OM}$ & & & & & & 0.77 & & 1.00 & \\
\hline $\mathrm{Co}-\mathrm{OM}$ & & & & & & & & & 1.00 \\
\hline e). & Fe-Rcs & Mn-Res. & Cu-Res. & Zn-Rce & Pb-Res. & Cd-Res. & Cr-Res. & Ni-Res. & Co-Rex \\
\hline Fe-Res. & 1.00 & & & & & & & & \\
\hline Mn-Res. & & 1.00 & & & & & & & \\
\hline Cu-Res & & & 1.00 & & & $\therefore$ & & & \\
\hline Zn-Res & & & & 1.00 & & & & & \\
\hline Pb-Res. & & & & & 1.00 & & & & \\
\hline Cd-Rcs & & & & -0.59 & & $1: 00$ & & & \\
\hline Cr-Res & & & & & & & 1.00 & & \\
\hline $\mathrm{Ni}-\mathrm{R}$ Cs & & & & & & & & 1.00 & \\
\hline Co-Res. & & & 0.67 & & & & & & 1.00 \\
\hline
\end{tabular}


Table (13): Loading of variables (9 metals) using PCA technique for the data set in the five fractions Lake Manzalah sediments.

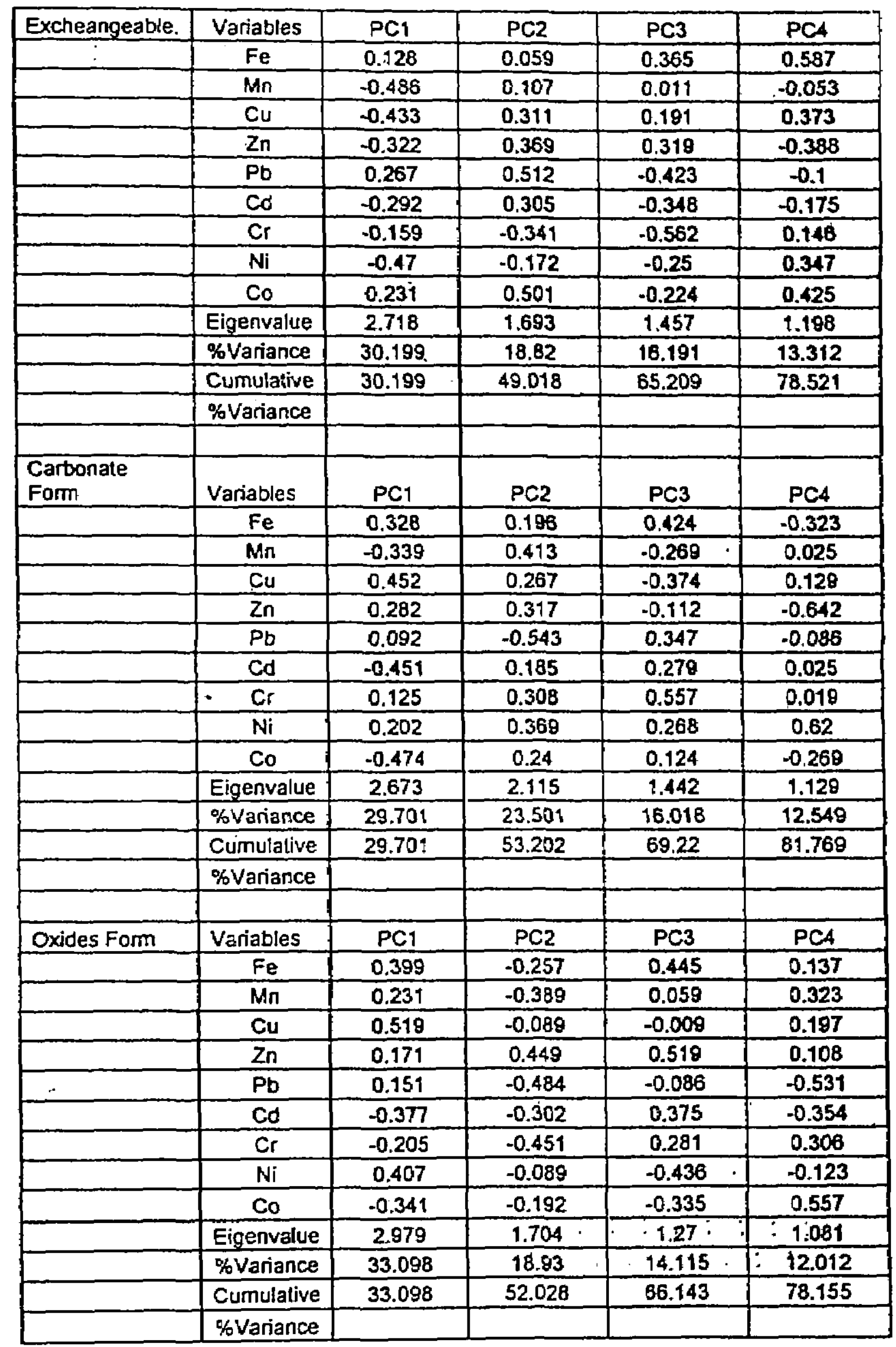


Table 13(Continued)

\begin{tabular}{|c|c|c|c|c|c|}
\hline Organic Form & Variables & $\mathrm{PC1}$ & $\mathrm{PC2}$ & PC3 & $\mathrm{PC}_{4}$ \\
\hline & $\mathrm{Fe}$ & 0.539 & -0.102 & 0.083 & \\
\hline & $M n$ & 0.365 & -0.291 & -0.149 & \\
\hline & $\mathrm{Cu}$ & 0.435 & 0.356 & -0.143 & \\
\hline & $\mathrm{Zn}$ & 0.205 & -0.076 & 0.805 & \\
\hline & $\mathrm{Pb}$ & 0.364 & -0.013 & -0.415 & \\
\hline & $\mathrm{Cd}$ & 0.199 & 0.548 & -0.112 & \\
\hline & Cr & 0.164 & -0.392 & 0.04 & \\
\hline & $\mathrm{Ni}$ & 0.016 & 0.56 & 0.288 & \\
\hline & Co & 0.382 & -0.072 & 0.182 & \\
\hline & Eigenvalue & 2.98 & 2.559 & 1.048 & \\
\hline & $\%$ Variance & $33 .\{12$ & 28.43 & 11.646 & \\
\hline & Cumulative & 33.112 & 61.543 & 73.188 & \\
\hline & $\%$ Variance & & & & \\
\hline Residual Form & Variables & $\mathrm{PC} 1$ & $\mathrm{PC2}$ & PC3 & \\
\hline & $\mathrm{Fe}$ & 0.539 & -0.102 & 0.083 & \\
\hline & $\mathrm{Mn}$ & 0.365 & -0.291 & -0.149 & \\
\hline & $\mathrm{Cu}$ & 0.435 & 0.356 & -0.143 & \\
\hline & $\mathrm{Zn}$ & 0.205 & -0.076 & 0.805 & \\
\hline & $\mathrm{Pb}$ & 0.364 & -0.013 & -0.415 & \\
\hline & $C d$ & 0.199 & 0.548 & -0.112 & \\
\hline & $\mathrm{Cr}$ & 0.164 & -0.392 & 0.04 & \\
\hline & $\mathrm{Ni}$ & 0.016 & 0.56 & 0.288 & \\
\hline & Co & 0.382 & -0.072 & 0.182 & \\
\hline & Eigenvalue & 2.98 & 2.559 & 1.048 & \\
\hline & \%Variance & 33.112 & 28.43 & 11.646 & \\
\hline & Cumulative & 33.112 & 61.543 & .73 .188 & \\
\hline & \%Variance & & & & \\
\hline
\end{tabular}




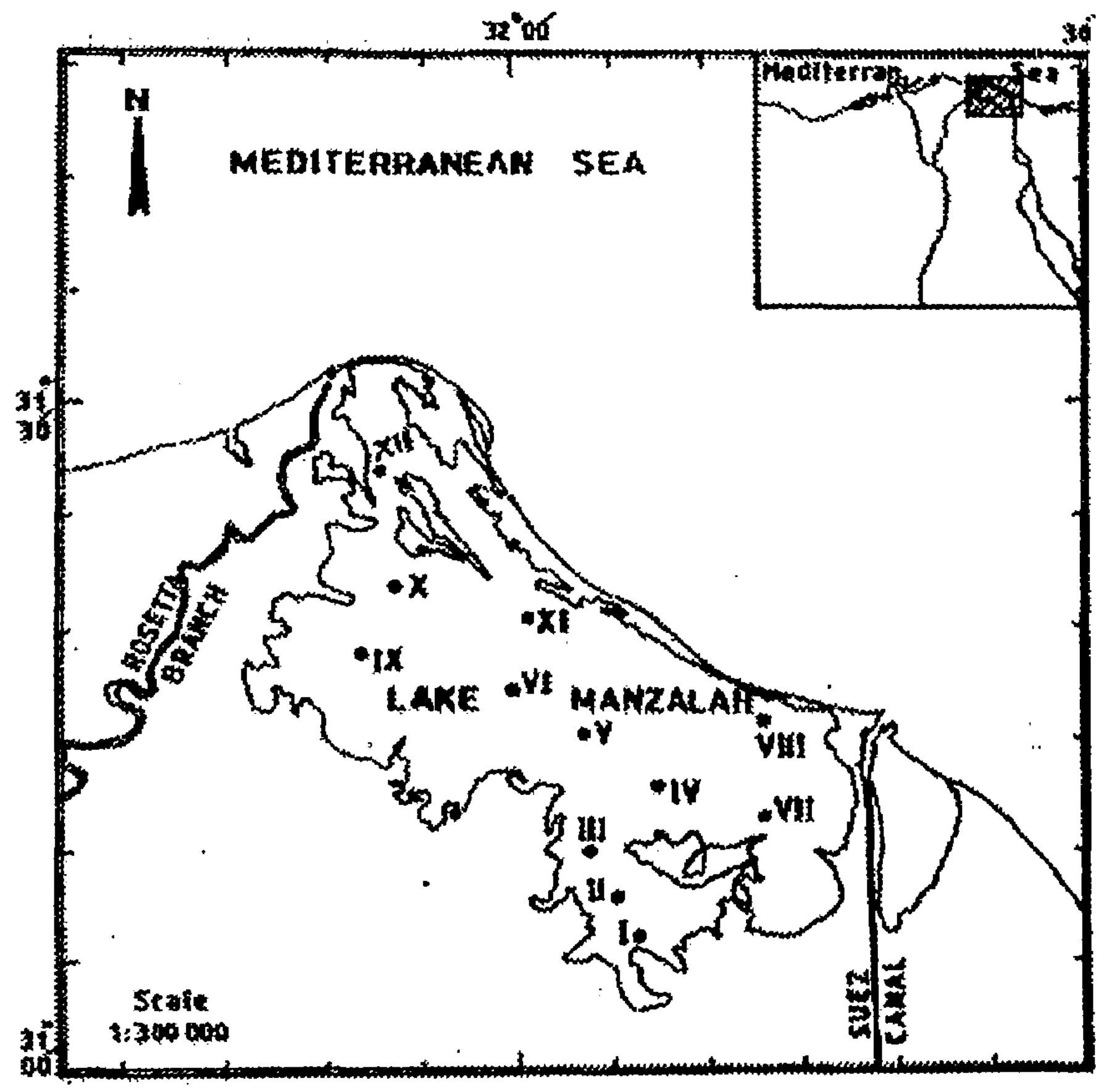

Figure 1: Locations of Sedimant Sampling. 


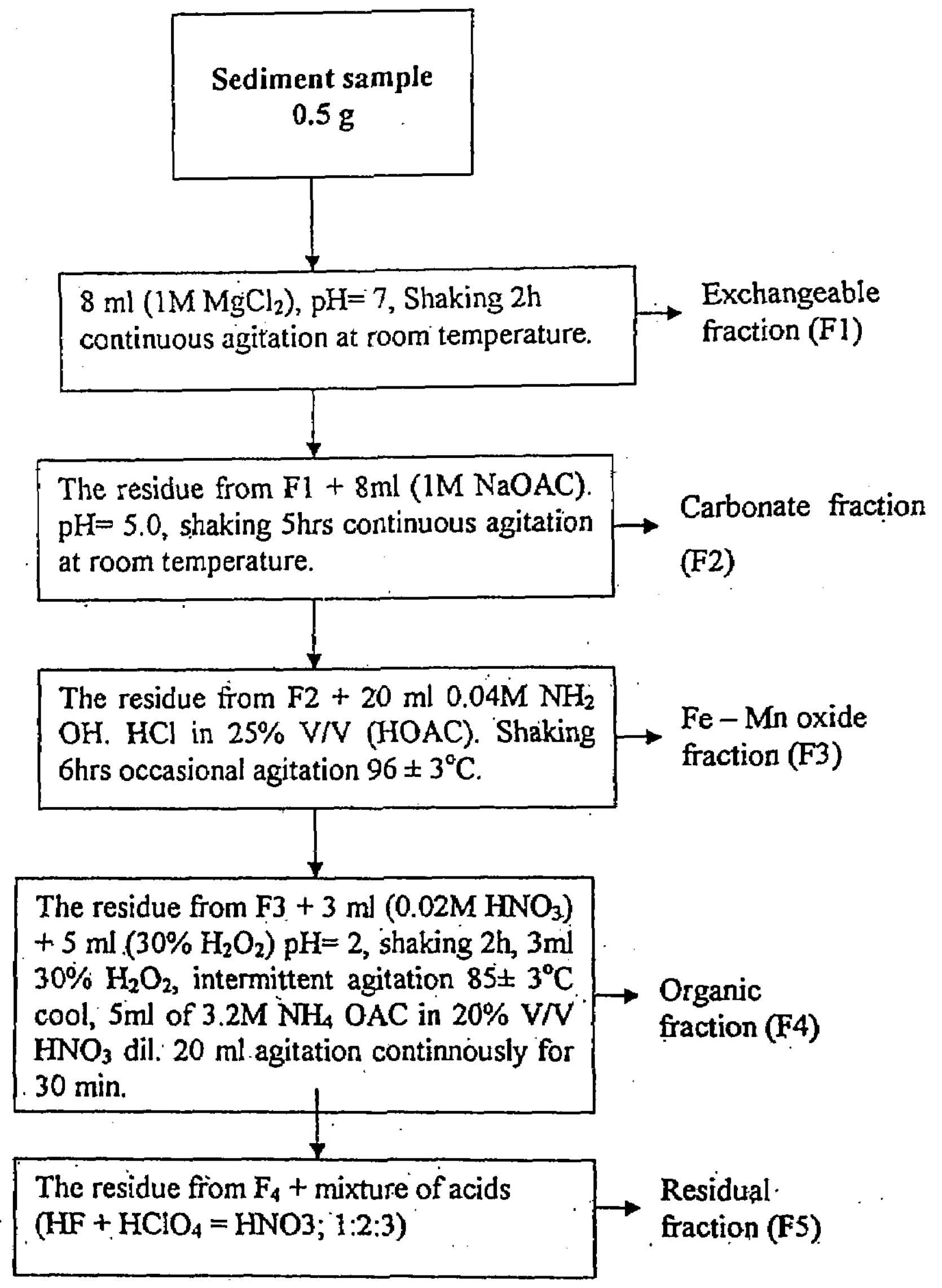

Fig. 2. Schematic diagram of sequential extraction procedure for trace metals (Tessier et al., 1979). 

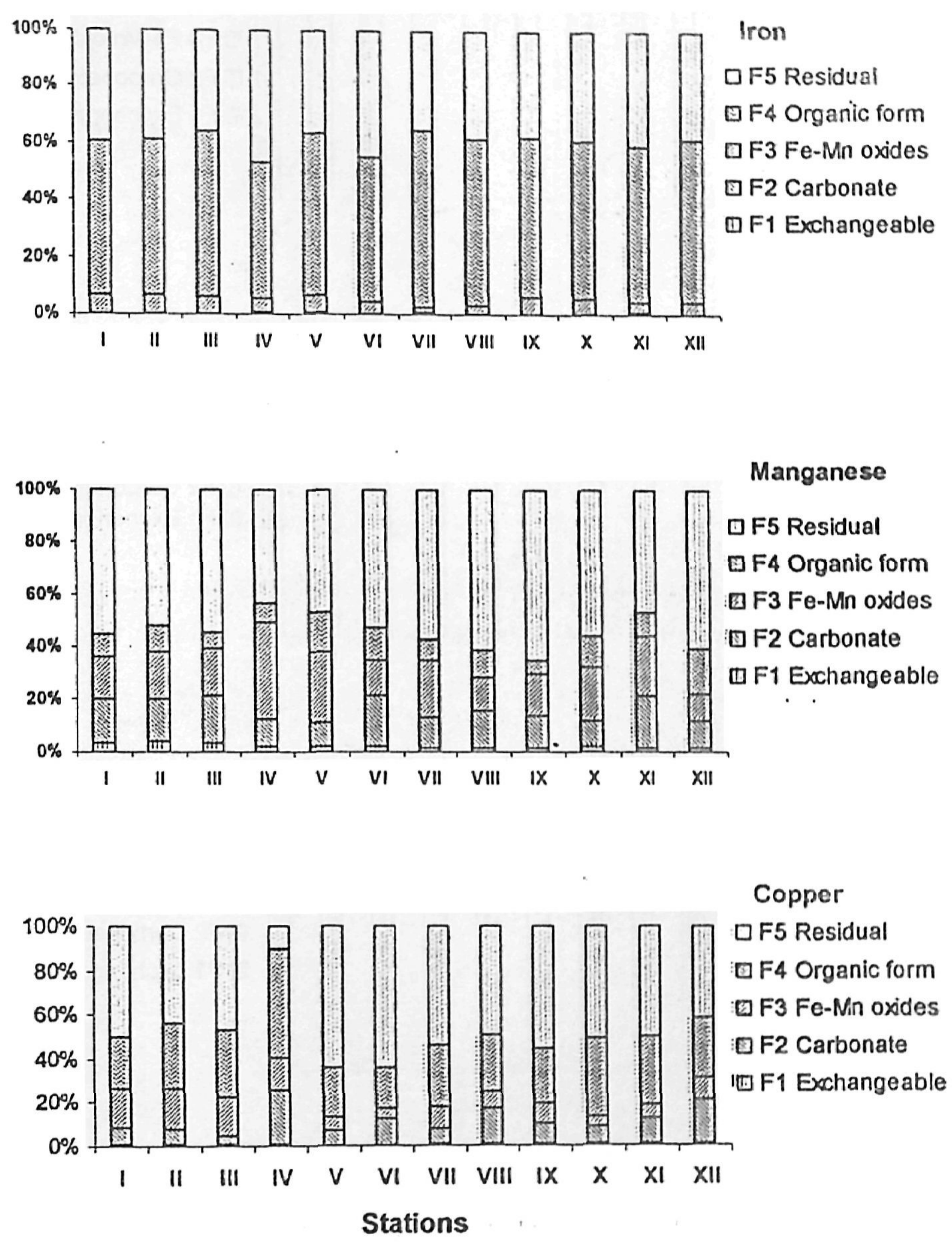

Figure 3. percentage of $\mathrm{Fe}, \mathrm{Mn}$ and $\mathrm{Cu}$ in the five fractions to the total concentration of Lake Manzalah sediments 
Zinc

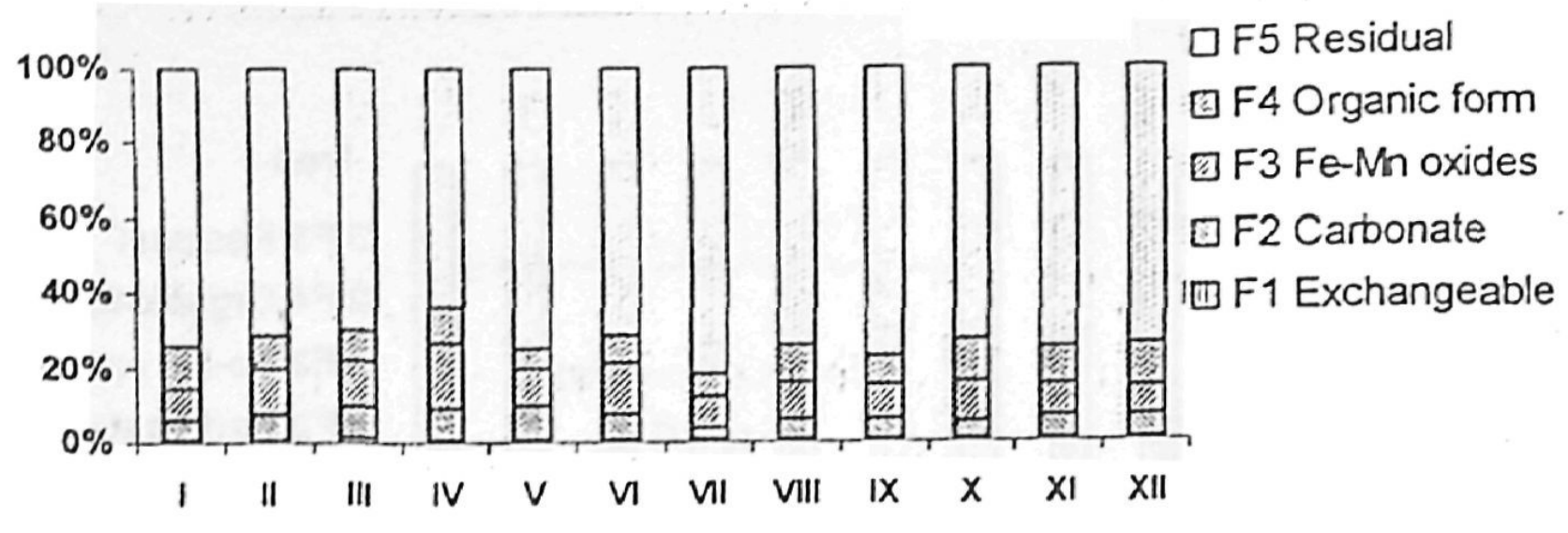

Lead
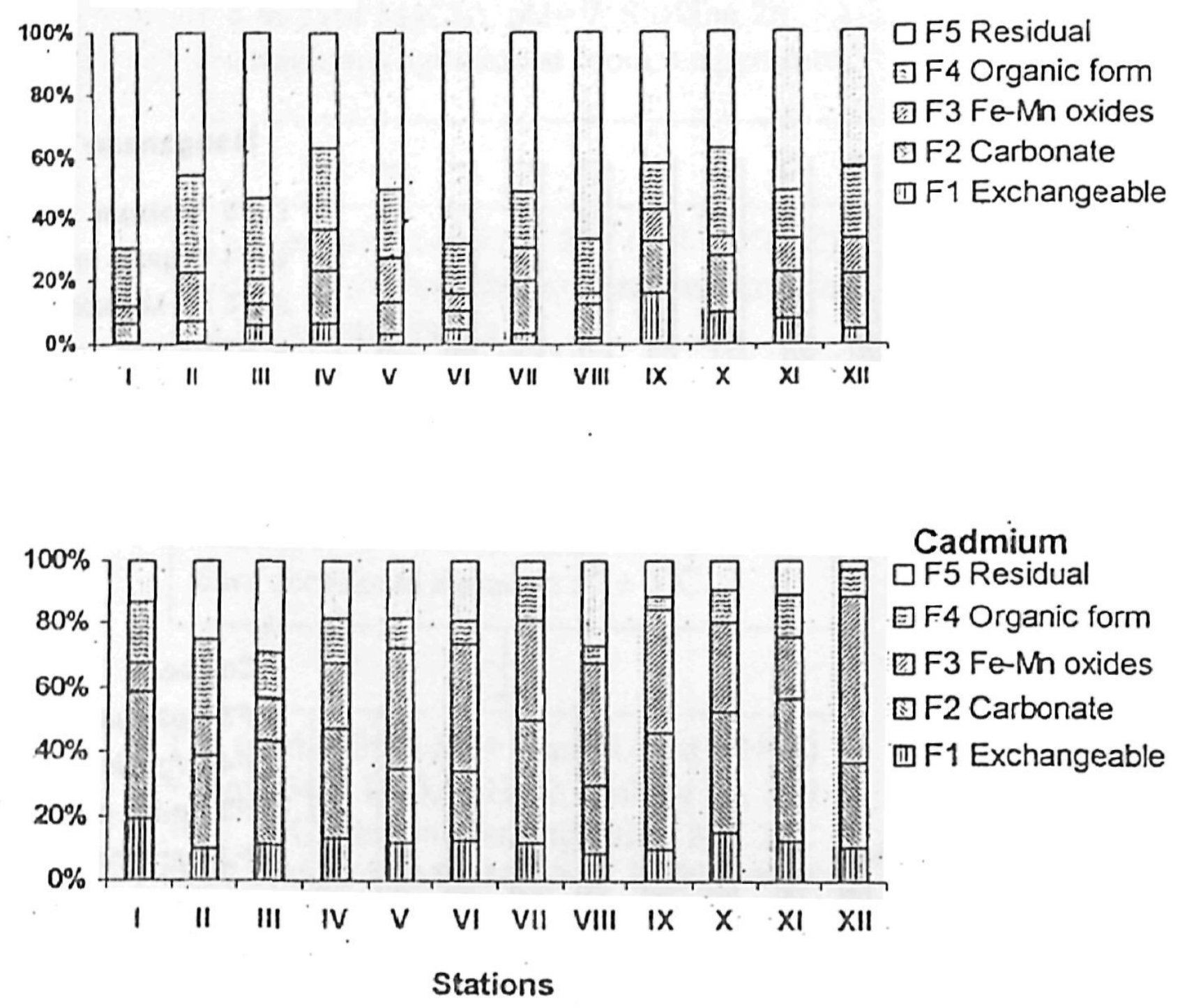

Figure 4. percentage of $\mathrm{Zn}$ and $\mathrm{Cd}$ in the five fractions to the total concentration of Lake Manzalah sediments 


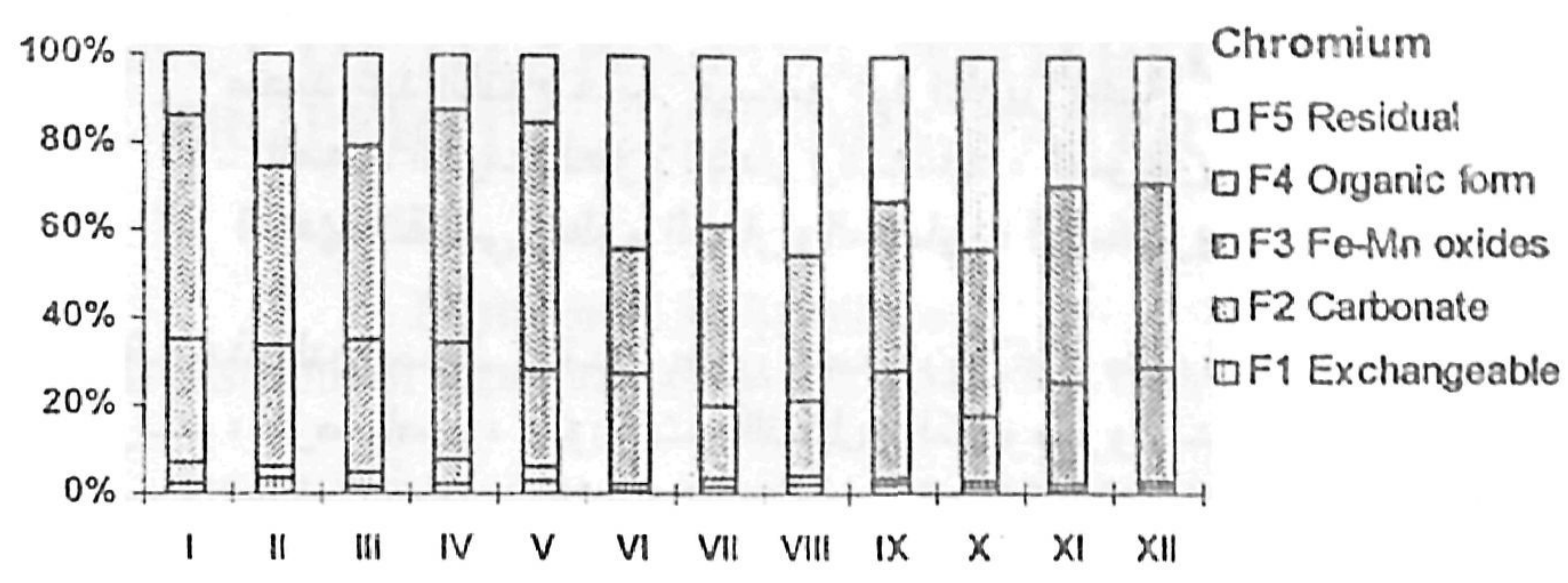

Nickel

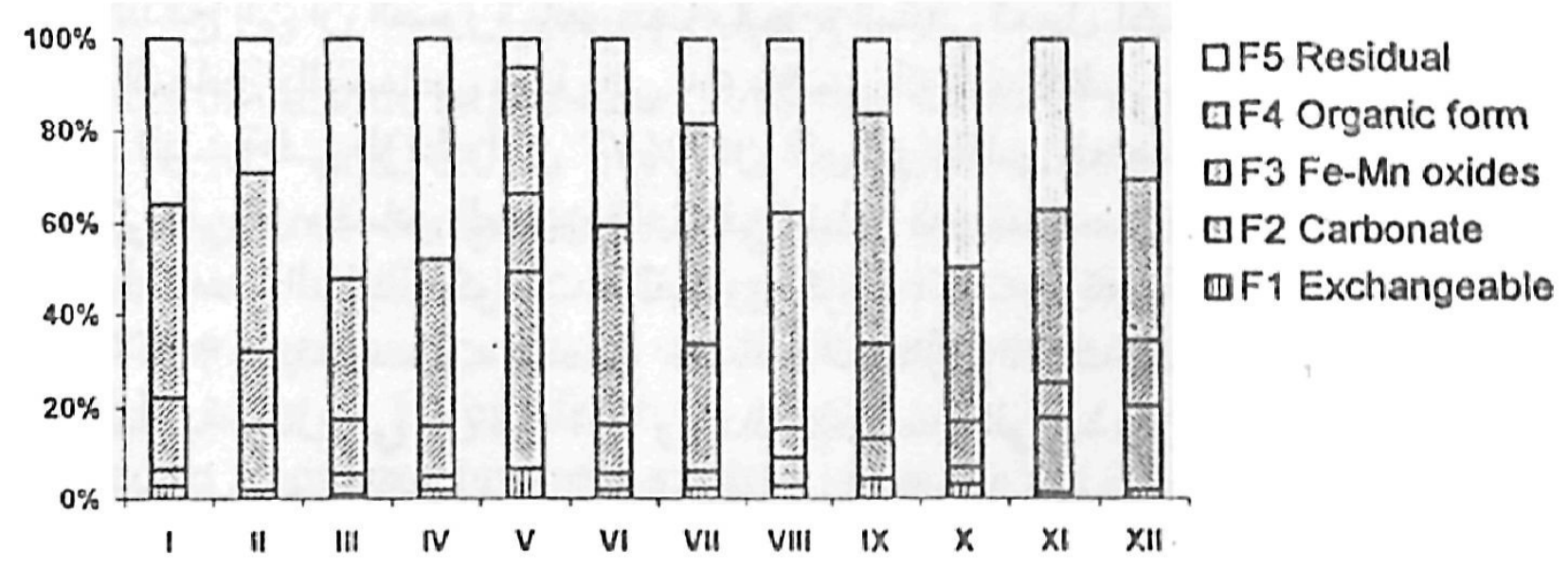

Cobalt

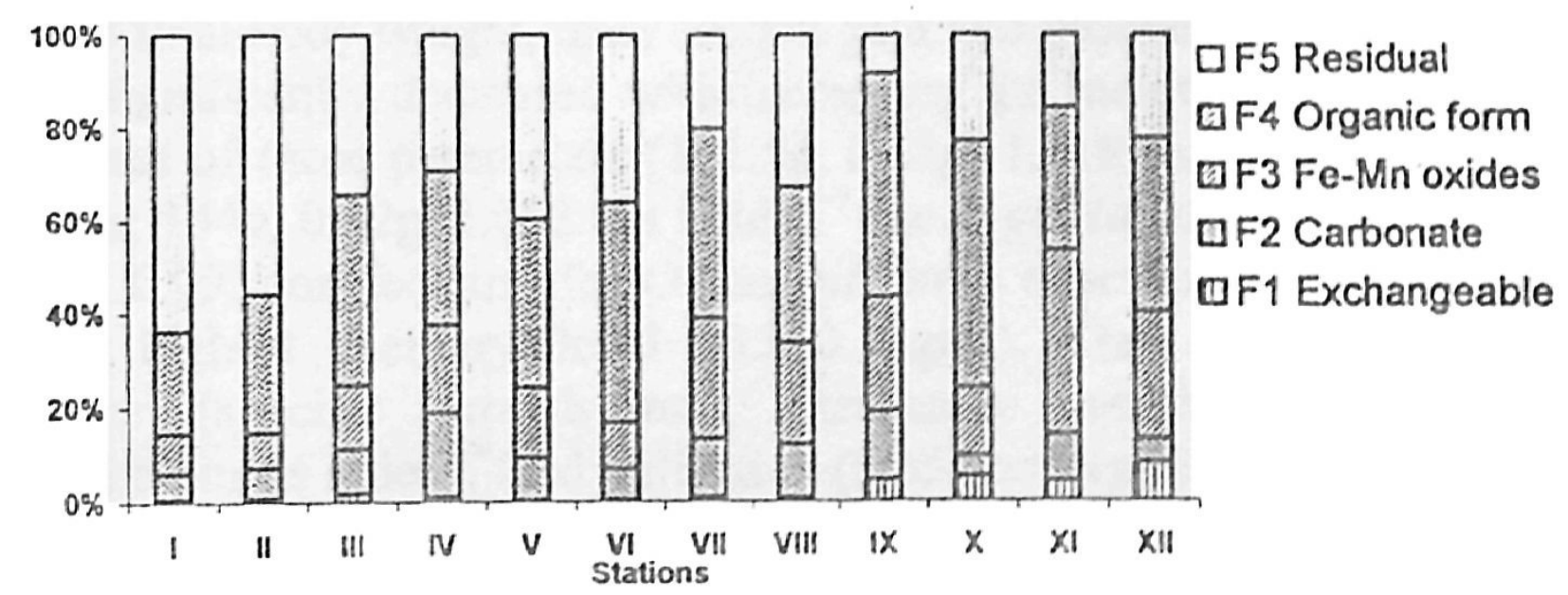

Figure 5. Percentage of $\mathrm{Cr}, \mathrm{Ni}$ and $\mathrm{Co}$ in the five fractions to the total concentration Lake Manzalah sediments 